\title{
PENGARUH PELATIHAN DAN INSENTIF TERHADAP KINERJA GURU PADA SD NEGERI 173396 DOLOKSANGGUL KABUPATEN HUMBANG HASUNDUTAN
}

\author{
Ayu Fitrida Purba \\ Prodi Manajemen Informatika Amik Widyaloka Medan \\ Jl. T.B.Simatumang No.161 Kecamatan Medan Sunggal Kota Medan Provinsi Sumatera \\ Utara \\ Ayupurba1995@gmail.com
}

\begin{abstract}
Abstrak
Penelitian ini dilakukan di SD Negeri 173396 Doloksanggul Kabupaten Humbang Hasundutan: (1) bagaimana pengaruh pelatihan terhadap kinerja guru (2) bagaimana pengaruh insentif terhadap kinerja guru (3) pengaruh pelatihan dan insentif terhadap kinerja guru. Sampel penelitian sebanyak 32 orang guru. Metode pengumpulan data menggunakan angket dengan model skala Likert 5 alternatif jawaban. Analisi data yang diguenkan regresi linear berganda. Hasil penelitian menunjukkan: (1) terdapat pengaruh positif dan signifikan pelatihan terhadap kinerja guru, (2) terdapat pengaruh positif dan signifikan insentif terhadap kinerja guru, (3) terdapat pengaruh positif dan signifikan pelatihan dan insentif secara bersama-sama terhadap kinerja guru kriteria determinasi sebesar $31,3 \%$ sisanya 68,7 dijelaskan variavel lain.
\end{abstract}

\section{Kata Kunci : Pelatihan, Insentif dan Kinerja Guru}

\begin{abstract}
This research was conducted at public Elementary School No: 173396, Doloksanggul, Humbang Hasundutan Regency: (1) how the influence of training on teacher's perfomance, (2) how the influence of incentives on teacher's perfomance (3) the effect of training and incentives on teacher's perfomance. The research sample was 31 teachers. The method of data colletion uses a question naire with the Likert scale model 5 alternative answers. Data analysis used multiple linear regression. The result showed: (1) there was a postive and significant effect of training on teacher's perfomance, (2) there was a positive and signicant effect of incentives on teacher's perfomance, (3) there was positive and significant effect of training and incentives together on teacher's perfomance. Determination criteria of $31,3 \%$ which means training and incentives are able to explain variation, teacher's perfomance is $31,1 \%$ The Remaining $68,7 \%$ is explained by others variables .
\end{abstract}

\section{Keywords : Training, incentives and teacher's perfomance}

\section{PENDAHULUAN}

Pendidikan tidak terlepas dari keseluruhan kegiatan manusia baik dalam keluarga, sekolah dan ditengah masyarakat. Hampir semua negara menetapkan variable Pendidikan 
sebagai sesuatu yang penting dan utama dalam konteks pembangunan bangsa dan negara. Begitu juga Indonesia, menetapkan Pendidikan sebagai sesuatu yang sangat penting dan utama. Hal ini dapat dilihat dalam pembukaan Undang-Undang Dasar 1945 alinea ke-IV yang menegaskan bahwa salah satu tujuan nasional Bangsa Indonesia adalah mencerdaskan Kehidupan Bangsa.

Pemerintah dan bangsa Indonesia terus berupaya meningkatkan mutu pendidikan. Keberhasialan pendidikan suatu negara sangat ditentukan oleh keberadaan guru. Guru adalah pendidik professional dengan tugas utama mendidik, mengajar, membibing, mengarahkan, melatih, menilai, dan mengevaluasi peserta didik pada pendidikan anak usia dini, pendidikan dasar, dan pendidikan menengah jalur pendidikan formal. Peran guru dalam penyelengaraan pendidikan forml sangat dominan untuk mencapai pendidikan yang berkualitas. Untuk tercaainya pendidikan yang berkualitas diperlukan guru yang professional dan berkualitas.

Dalam upaya meningkatkan kinerja guru baik dalam hal kompetensi maupun keterampilan dalam proses pembelajaran, sekolah perlu memperhatikan factor-faktor yang dapat meningkatkan kinerja guru tersebut dalam mengembangkan segala potensinya, salah satunya yanitu dengan mengikuti pendidikan dan pelatihan. Pendidikan dan pelatihan memberikan kesempatan kepada guru untuk mendapatkan pengetahuan, keterampilan, sikap baru, yang mengubah perilakunya yang pada akhirnya akan meningkatkan kinerja serta akan berdampak pula pada peningkatan prestasi belajar siswa. Pendidikan dan pelatihan dilakukan sebagai sarana meningkatkan keterampilan dan pengetahuan umum bagi guru.

Berdasarkan hasil pra penelitian yang peneliti lakukan pada bulan februari di SD Negeri 173396 Doloksanggul kabupaten Humbang Hasundutan, sebagian guru sudah menunjukkan kinerja yang baik dalam menjalankan tugas dan fungsinya. Akan tetapi, masih ada kinerja guru yang rendah antara lain: mengajar secara monoton tanpa adanya inovasi pembelajaaran, masih ada guru yang terlambat masuk kelas dan keluar kelas sebelum jadwal pergantian jadwal jam pembelajaran. Selain itu, ada pula guru yang tanpa adanya persiapan yang matang dan kurang penguasaan terhadap materi ajar sehingga hanya sekedar menyampaikan materi. Maka peneliti berpadangan bahwa ada hal yang menjadi factor sehingga terjadi hal seperti itu.

SD Negeri 173396 Doloksanggul kabupaten Humbang Hasundutan juga melakukan penilaian kinerja kepada seluruh guru yang bekerja pada setiap tahunnya. Penilaian kinerja menyangkut beberapa aspek antara lain sikap, kejujuran, semangat kerja, kompetensi dan berbagai aspek lainnya yang dinilai. Dari pengamatan yang dilakukan ditemukan fenomena bahwa guru yang memberikan hasil yang cukup baik atas pekerjaannya.

Berdasarkan latar belakang yang telah diuraikan diatas, maka penulis ingin mengetahui bagaimana pengaruh pelatihan dan pengembangan terhadap kinerja guru, maka penulis tertarik memilih judul "PENGARUH PENDIDIKAN DAN PELATIHAN TERHADAP KINERJA GURU PADA SD NEGERI 173396 DOLOKSANGGUL KABUPATEN HUMBANG HASUNDUTAN".

\section{METODOLOGI PENELITIAN}

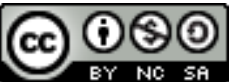


Penelitian ini adalah penelitian korelasi yang dimaksud untuk mengetahui pengaruh pelatihan terhadap kinerja guru di SD Negeri 173396 doloksanggul Kabupaten Humbang Hasundutan.

Penelitian ini adalah penelitian kuantitatif yang di disain dalam bentuk hubungan sebab akibat (korelasional), untuk mengetahui pengaruh variabel bebas dan terikat.

\section{HASIL DAN PEMBAHASAN}

\section{A. Teknik Analisis Data}

\section{Uji Regresi Linear Berganda}

Hasil analisi regresi diperoleh koefisien untuk XI $=0,141$ nilai ini dapat dilihat pada kolom $\mathrm{B}$ pada baris Pelatihan X2 $=0,299$ dilihat pada kolom B pada baris insentif dan konstanta sebesar 36,862 dilihat pada kolom B pada baris konstan. Sehingga model persamaan regresi yang diperoleh adalah sebagai berikut:

$$
\mathrm{Y}=36,862+0,141_{\mathrm{X} 1}+0,{ }_{299} \mathrm{X} 2 .
$$

Tabel 4.19

Coefficients $^{a}$

\begin{tabular}{|c|c|c|c|c|c|}
\hline \multirow[b]{2}{*}{ Model } & \multicolumn{2}{|c|}{ Unstandardized Coefficients } & \multirow{2}{*}{$\begin{array}{c}\text { Standardized } \\
\text { Coefficients } \\
\text { Beta }\end{array}$} & \multirow[b]{2}{*}{$\mathrm{T}$} & \multirow[b]{2}{*}{ Sig. } \\
\hline & B & Std. Error & & & \\
\hline (Constant) & 36,862 & 7,659 & & 4,183 & , 000 \\
\hline Pelatihan & , 141 & , 190 & 177 & 3,742 & ,014 \\
\hline insentif & 299 & , 173 & ,413 & 2,735 & ,023 \\
\hline
\end{tabular}

a. Dependent Variable: pelatihan dan insentif

Sumber : Pengolahan data dengan menggunakan program spss

\section{Uji Normalitas}

Metode paling handal adalah melihat normal probability plot yang membandingkan distribusi kumulatif dan distribusi normal. Distribusi normal akan membentuk satu garis lurus diagonal. Jika distribusi normal, maka garis yang menggambarkan data yang sesungguhnya akan menjadi garis diagonalnya.

\section{Gambar 4.2}


Volume 1, Nomor 2,Oktober 2020: halaman 40-46

https://jurnal.amikwidyaloka.ac.id/index.php/awl

jurnal@amikwidyaloka.ac.id / editor.jurnalwidya@gmail.com

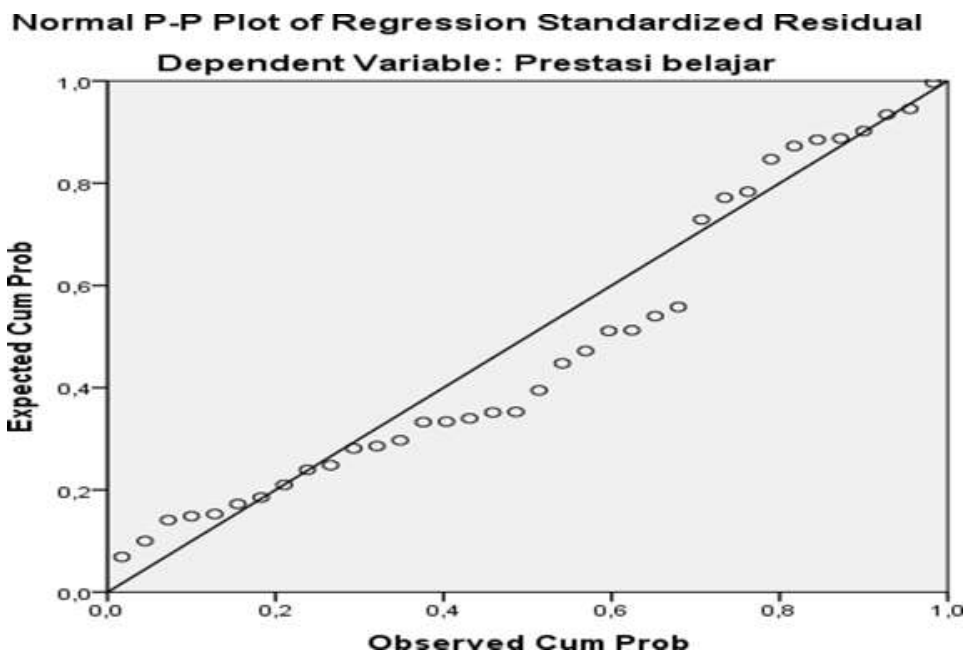

\section{Pengujian Hipotesis Secara Parsial (Uji t)}

Untuk menguji hipotesis yang menyatakan variabel Pelatihan XI dan Insentif X2 secara parsial mempengaruhi Kinerja Guru, maka digunakan uji-t, pengujian hipotesis dilakukan dengan membandingkan besarnya taraf signifikan penelitian dengan taraf $95 \%$ atau $\alpha<0,05$ dan hasil thitung dapat dilihat pada tabel 4.19:

Tabel 4.19

\begin{tabular}{|c|c|c|c|c|c|}
\hline \multirow[b]{2}{*}{ Model } & \multicolumn{2}{|c|}{ Unstandardized Coefficients } & \multirow{2}{*}{$\begin{array}{c}\text { Standardized } \\
\text { Coefficients } \\
\text { Beta }\end{array}$} & \multirow[b]{2}{*}{$\mathrm{T}$} & \multirow[b]{2}{*}{ Sig. } \\
\hline & B & Std. Error & & & \\
\hline $1 \quad$ (Constant) & 36,862 & 7,659 & & 4,183 & ,000 \\
\hline Pelatihan & ,141 & , 190 & ,177 & 3,742 & ,014 \\
\hline Insentif & ,299 & , 173 & ,413 & 2,735 & 023 \\
\hline
\end{tabular}

a. Dependent Variable: pelatihan dan insentif

Sumber : Pengelolaan data dengan menggunakan program SPSS 22

\section{Pengujian Hipotesis Secara Simultan (Uji F)}

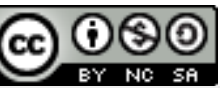


Volume 1, Nomor 2,Oktober 2020: halaman 40-46

Untuk mengetahui pengaruh kedua variabel bebas secara bersama-sama terhadap variabel terikat digunakan Uji F. Berdasarkan hasil pengolahan dengan program SPSS. 22 for windows dapat dilihat pada tabel 4.12 sebagai berikut:

Tabel . 4.12 Uji Simultan (Uji-F)

ANOVA $^{a}$

\begin{tabular}{|rr|r|r|r|r|r|}
\hline \multicolumn{2}{|l|}{ Model } & \multicolumn{1}{|c|}{$\begin{array}{c}\text { Sum of } \\
\text { Squares }\end{array}$} & Df & Mean Square & F & Sig. \\
\hline $1 \quad$ Regression & 111,453 & 2 & 55,726 & 6,608 &, $000^{\mathrm{b}}$ \\
& Residual & 244,547 & 29 & 8,433 & & \\
& & & & & \\
& Total & 356,000 & 31 & & & \\
\hline
\end{tabular}

a. Dependent Variable: kinerja guru

b. Predictors: (Constant), insentif, pelatihan

Sumber: Pengolahan data dengan menggunakan program SPSS 22

\section{Koefisien Determinasi (R2)}

Koefisien determinasi digunakan untuk melihat besarnya kontribusi variabel- variabel independent/bebas pelatihan (X1) dan Insentif (X2), terhadap variabel dependen yaitu Kinerja Guru Pada SD Negeri 173396 Doloksanggul kabupaten Humbang Hasundutan. Perhitungan koefisien determinasi dapat dilihat pada tabel 4.21:

Tabel Koefisien Determinasi $\left(\mathbf{R}^{2}\right)$

Model Summary ${ }^{\mathrm{b}}$

\begin{tabular}{|l|r|r|r|r|}
\hline Model & $\mathrm{R}$ & R Square & Square & \multicolumn{2}{|c|}{$\begin{array}{c}\text { Adjusted R } \\
\text { Estimate }\end{array}$} \\
\hline 1 &, $560^{\mathrm{a}}$ &, 266 & 2,90391 & 1,714 \\
\hline
\end{tabular}

a. Predictors: (Constant), insentif pelatihan

\section{B. Pembahasan Hasil Penelitian}


Salah satu faktor peningkatan kinerja guru yang adanya pelatihan dan insentif. Sekolah, pemerintah, dan organisasi, melakukan, program Pelatihan dan insentif, bagi setiap guru yang mengajar pada SD Negeri 173396 Doloksanggul kabupaten Humbang Hasundutan diharapkan mampu meningkatkan kemamouan pengetahuan dan keterampilan untuk menyelesaikan tugas dan tanggung jawab yang diberikan kepadanya.

Dengan adanya pelatihan dan insentif, diharpkan juga menghasilkan sumber daya manusia yang berkualitas dan mampu memberanikan kontribusi yang positif bagi organisasi. Pelatihan yang terarah pada peningkatan dan keahlian ssumber daya manusia yang berkaitan dengan jabatan atau fungsional pada masa sekarang, sedangkan insentif lebih berfokus pada pemberian kompensasi berupa uang diluar gaji pokok yang diterima guru.

Hasil analisis data menunjukkan bahwa nilai thitung variabel pelatihan adalah 3,742 dan ttabel 1,694. Nilai thitung lebih besar dari ttabel sehingga H0 ditolak, artinya pelatihan berpengaruh positif dan signifikan secara parsial terhadap kinerja guru.

Nilai thitung pada variabel insenti adalah sebesar 2,735 dan ttabel 1,694 nilai thitung lebih besar dari ttabel sehingga H0 ditolak, artinya insentif berpengaruh positif dan signifikan secara parsial terhadap kinerja guru. Nilai R2 sebesar 0,313 atau 31,3\% dan persamaan regresi linear berganda dari variabel pelatihan dan insentif $(\mathrm{X} 1, \mathrm{X} 2)$ dan kinerja guru $(\mathrm{Y})$ dengan persamaan regresi $\mathrm{Y}=36,862+0,141+0,299 \mathrm{X} 2$.

Dari program pelatihan dan insentif yang di berikan oleh SD 173396 Doloksangguk Kabupaten Humbang Hasundutan yang telah diikuti seluruh guru terdapat kenaikan kinerja guru dari tahun ketahun mulai dari tahun 2014-2018. Walaupun data tersebut sudah menunjukkan kinerja yang cukup baik akan tetapi diharapkan sekolah, pemerintah, organisasi dan lembaga pendidikan selalu memberikan Pelatihan dan Insentif, agar kinerja guru lebih baik lagi.

\section{Kesimpulan}

Dari hasil penelitian tentang pengaruh pelatihan dan Insentif, terhadap kinerja guru pada SD Negeri 173396 Doloksanggul Humbang Hasundutan, maka dapat ditarik kesimpulan sebagai berikut.

1. Pelatihan berpengaruh positif terhadap kinerja guru berdasarkan uji-t ternyata pelatihan berpengaruh positif dan signifikan terhadap kinerja guru.

2. Insentif berpengaruh positif terhadap kinerja guru berdarkan uji-t, ternyata insentif berpengaruh positif dan signifikan terhadap kinerja guru.

3. Pelatihan dan insentif berpengaruh positig terhadap kinerja guru berdasarkan uji-F, ternyata pelatihan dan insentig secara simultan berpengaruh signifikan terhadap kinerja guru.

4. Berdasarkan koefisien determinasi, ternyata model mampu menejelaskan variabel kinerja guru sebesar $31,3 \%$, sedangkan sisanya $68,7 \%$ dijelaskan variabel lainya.

\section{DAFTAR PUSTAKA}


[1] Bangun, Wilson. 2012. Manajemen Sumber Daya Manusia. Jakarta: Penerbit Erlangga.

Badan Pengembangan Sumber Daya Manusia Pendidikan dan Kebudayaan dan Penjamin Mutu Pendidikan, Kementerian Pendidikan dan Kebudayaan Tahun 2012 tentang "Kebijakan Pengembangan Profesi Guru"

[2] Choliq, H. Abdul. 2014. Pengantar Manajemen, Yogyakarta: Penerbit Ombak.

[3] Daryanto \& Bintoro. 2014. Manajemen Diklat. Yogyakarta: Penerbit Gaya Media.

[4] Hamzah, B Uno.2014. Profesi Kependidikan Problema, Solusi dan Reformasi Pendidikan di Indonesi. Jakarta: PT Bumi Aksara.

[5] Hasibuan, Malayu Sp. 2016. Manajemen Sumber Daya Manusia Edisi Revisi, Cetakan kedua belas, Jakarta: Bumi Aksara.

[6] Mangkunegara, A.A. Anwar Prabu, 2016. Manajemen Sumber Daya Manusia Perusahaan. Bandung: PT Remaja Rosdakarya.

[7] Musfah, Jejen. 2016. Peningkatan Kompetensi Guru: Melalui Pelatihan dan sumber Belajar Teori dan Praktik. Bogor: Kencana Prenada Media Group.

[8] Peraturan pemerintah (PP) Nomor 101 Tahun 2000 tentang Pendidikan dan Pelatihan Jabatan Pegawai Negeri sipil. Pdf

[9] Ramadhan, Ilham. 2014. Pengaruh Pendidikan dan Pelatihan Terhadap Produktivitas

Kerja Karyawan Pada KUD Trisula Kabupaten Majalengka. Tesis. Jakarta: Universitas Indonesia

[10] Sugiyono, 2016. Metode Penelitian Kombinasi. Bandung: Alfabeta

[11] Supardi. 2014. Kinerja Guru. Jakarta: PT Raja Grafindo Persada.

[12] Tika, Pabundu. 2014. Budaya Oganisasi dan Pningkatan Kinerja Perusahaan. Jakarta: Bumi Aksara.

[13] Wahyudi, Imam. 2014. Panduan Lengkap Administrasi Guru, Jakarta: PT Prestasi Pustaka Karya

[14] Wahyudi, Imam. 2012. Mengejar Profesionalisme Guru (Strategi Praktis Mewujudkan Citra Guru Profesional). Jakarta: PT Prestasi Pustaka Karya. 